\title{
Dam Politics in Northern Nigeria: The Case of the Kafin Zaki Dam
}

\author{
Kole Ahmed Shettima
}

\begin{abstract}
Considerable political contention has developed over the dams and large-scale irrigation schemes in northern Nigeria. The reasons are the resettlement of peaple that they require as well as their environmental effects, their economic inefficiency and other social consequences. This article discusses these issues with reference specifically to the Kafin Zaki Dam proposal, challenging the conventional image of an alignment of international organizations and domestic elites on one side and grassroots forces on the other. The conclusion is that the political contest is carried out essentially at the elite level and that state and international agencies at times do oppose mega-projects that displace people and disrupt ecological processes.
\end{abstract}

\section{Précis}

Des démêlés politiques considérables se sont développés autour de la question des barrages et de l'irrigation à grande échelle au Nord-Nigeria. Les raisons en sont: les relocalisations de populations que ces projets entrainent, leur impact sur l'environnement, leur inefficacité économique, ainsi qu'une kyrielle d'autres conséquences sociales. Le présent article aborde ces questions en se référant spécifiquement au cas du projet de barrage du Kafin Zaki, et remet en question la conception conventionnelle $d^{\prime}$ un face a face sur cette question entre les organisations internationales et les élites locales d'un côté et les forces $d u$ terroir de l'autre. La conclusion est plutôt que le conflit politique se livre principalement au niveau élitaire, et que les agences nationales et internationales en viennent avec le temps à s'opposer à ce type de mégaprojet qui déplace massive-

Kole Ahmed Shettima is Adjunct Professor of Political Science, Department of Political Science, University of Toronto, Toronto. ment les populations et perturbe profondément le processus écologique.

\section{Introduction}

Large scale irrigation schemes and dams dot the landscape of northern Nigeria. There are criticisms of these projects, funded in the 1970s. Problems identified include economic inefficiency, class-bias, health hazards and environmental effects (Watts 1987). However, the issue of resistance to irrigation and dam projects and especially the role of factions of international agencies and some parts of the state has not been explored in this regard. Indeed, most of the literature on irrigation schemes in northern Nigeria has only focused on the negative roles of international and national agencies (ibid., 1987).

There are many examples of international agencies, multilateral and bilateral, playing negative roles of environmental destruction. However, in the case of the Kafin Zaki Dam project in the Yobe Basin, these agencies worked together to successfully to stop construction, in conjunction with some parts of the Nigerian state and Nigerian organisations. This case study questions the assumption of monolithic states, governments and international agencies prevalent in much of the development studies literature.

\section{The Geography and Ecology of the Yobe Basin}

The Kumadugu River's Yobe Basin is located in the northeast of northern Nigeria and covers about 9 percent of the country's land. Kumadugu Yobe has a catchment area of about 85,000 square kilometres. Its three main tributaries are the River Hadejia, the River Jama'are and the Kumadugu Gana. The Hadejia has the largest catchment area of 30,000 square kilometres at the western end of the basin, the Jama'are has 20,000 square kilometres and joins the Hadejia near Gashua to form the Hadejia-Jama'are. The River HadejiaJama'are meets the Kumadugu Gana near Geidam to form the Kumadugu Yobe (NEAZDP 1990, 9).

Nearly all of northern Nigeria is an ecologically sensitive zone. Desert expansion is the most serious environmental hazard. In recent years as much as 38 percent of the land is lost to desertification, and about 30 million people have been affected. The rate of desertification can be as high as 35 kilometres per year. In the 1972-73 drought alone, cattle mortality was at 20 percent. These ecological shifts are due to climatic changes, population increase and livestock pressure. According to the World Bank (1990, 17), human activities rather than climatic changes are the most significant causes of environmental variation. They include bush burning, human population movement, overgrazing and the increased use of mechanical methods of land clearing. Apart from these factors, major causes of environmental stress are engineering and agronomic biases of water resource development and management (Gadzama 1991, 9).

Ecological realities coupled with regional politics, "developmentalism," nationalism and the oil boom have been invoked to make a case for dam reservoirs in northern Nigeria. The construction of water reservoirs are meant for urban water supply and large scale irrigation projects. In the Yobe Basin, there are twenty-two dams existing, under construction and proposed with a catchment area of 31,303 square kilometres (NEAZDP $1990,16)$. Traditionally, surface water, wells and small dams have been used for urban water supply. Similarly, flooding, shadoof (a suspended pole with a bucket at one end and a weight at the other), wells, calabash, and other hand-held-bailer irrigation methods 
The Upper Komadougou-Yobe Basin

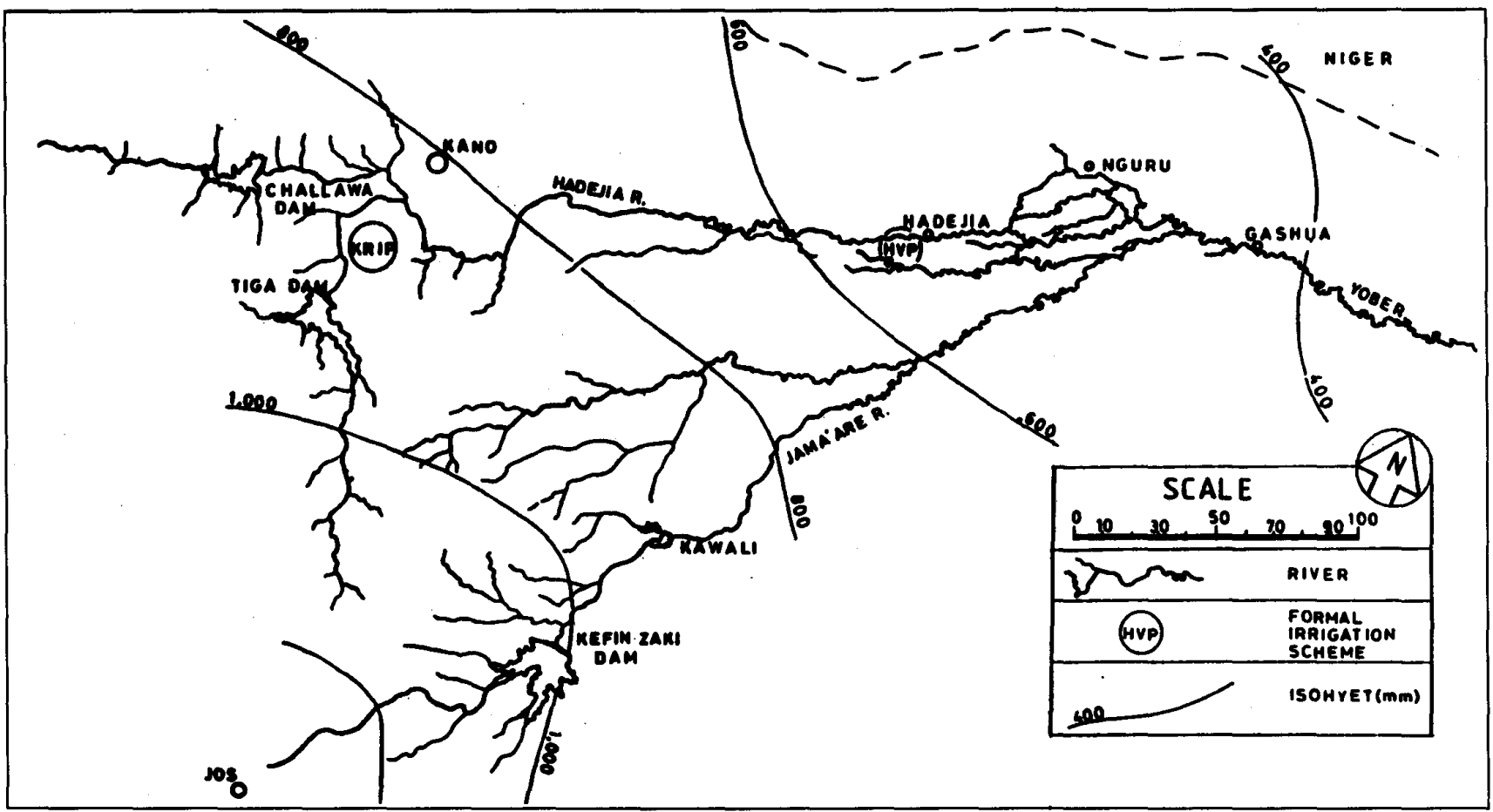

Source: Hadejia-Nguru Wetlands Conservation Project and the National Institute for Policy and Strategic Studies, Workshop on the Management of the Water Resources of the Komadugu-Yobe Basin, Kuru, 1st-2nd April 1993 (Kuru: National Institute Press, 1993 ), 35.

have been used in agriculture. Later, diesel-driven pumps and tube wells were introduced for the purpose of small-scale irrigation.

There are three major dams in the upstream region of the Yobe Basin. These include Tiga, Challawa and Bagauda. All these dams are around Kano. They provide water to the city of Kano and the Kano Irrigation Project Phase 1. The biggest of the dams is Tiga which was constructed 1971-74 (NEAZDP 1990, 16). River regulation has potential beneficial effects of reducing harmful flooding of agricultural land downstream, butcould have the negative effects of undermining flooding of the large fadama (flood plain) on which millions of people depend for traditional agriculture and irrigation, livestock grazing, and the recharging of the aquifers. Social conflicts due to loss of livelihood and the threat of displacement are some of the consequences.

\section{The Kafin Zaki Dam Proposal}

The damming of the river systems in northern Nigeria has instigated debates on the merits and demerits of such projects. A case in point is the Kafin Zaki Dam. On the one hand, a disparate interest group has been doggedly championing the cause of the project. On the otherhand, a loose strategic alliance of various institutions, individuals and organisations, foreign and domestic, successfully lobbied against the construction of the Kafin Zaki Dam. I shall name and discuss the groups in the debate on the merits and demerits of damming in the Yobe Basin, and the strategies and arguments invoked.

The Kafin Zaki Dam has an intellectual origin in theSchultz report funded by the Canadian International Development Agency and an earlier study funded by the United States Agency for International Development (HNWCP and NIPSS 1993, 19;
NEAZDP 1990). The 1972-74 drought in the Sahel was the proximate impetus for the project. But it was only during the Shagari regime (1979-83) that a contract was awarded for the project to Julius Berger, a German construction company. In 1984, the Buhari regime (1984-85) terminated the contract as part of its budgetary control measure, but that decision was reversed in December 1992 by the Babangida regime (1985-93). The latter requested Julius Berger to continue the project at a cost of N10 billion. ${ }^{1}$ It was expected that on completion of the project an area of 84,000 hectares would be irrigated. In 1994, the Abacha regime (1993present) terminated the contract and later appointed a judicial commission of inquiry under Justice Sanusi Ciroma Yusuf. The Commission was mandated to look into the origin and scope of the project, the manner and worth of its contract, as well as the role of staff in the Ministry of Water Resources and

Refuge, Vol. 16, No. 3 (August 1997) 
Rural Development (New Nigerian April 8, 1993).

\section{Support for the Kafin Zaki Dam}

The argument in support of the dam is led by a powerful interest group. The Schultz report intellectually rationalises the need for the project while Julius Berger, the most important construction company in Nigeria, lobbies in its support. Most of the important constructions in Abuja, the new federal capital, are executed by the company. Indeed, the new capital is often referred to as Berger city. Similarly, the company has on its board some of the most powerfulindividuals in the country.

Another important source of support for the project is political/bureaucratic. In December 1992 when the government authorised the company to proceed, the Minister responsible for water resources was Abubakar Hashidu. Hashidu was the former General Manager of the HadejiaJama'are River Basin Development Authority. In fact, the contract was awarded within the last week of his tenure as Minister. In addition, both Hashidu and the then Governor of the Central Bank, Abdulkadir Ahmed, come from the area where the projects are located.

Geopolitically, the dam is situated in an area which has always provided political support to the mainstream of northern Nigeria politics. They also belong to the Hausa-Fulani ethnic group. In contrast, the downstream users in Yobe and Borno states are labelled as minority ethnic groups. Politically, this group generally supports parties that oppose the mainstream of northern Nigerian politics.

The support for the project is invoked by bureaucrats using nationalist rhetoric. Irrigation is justified as a strategy for national food security. The alternative to irrigation is characterised as undermining national self-reliance. For example, in reaction to criticisms of the project Aminu (1991, 1805) accuses the critics of Kafin Zaki Dam of needlessly involving environmental issues and losing sight of the benefits of the project. The problem, according to the government, is drought and not irrigation schemes. This conclusion was reached despite the fact that the Ministry has not carried out environmental impact surveys. Dubious figures are officially used to minimise the impact of the projects on the downstream users, e.g. that the Kafin Zaki Dam is only $\mathbf{1 0 . 6}$ percent of the catchment area of the Yobe Basin. Furthermore, faith is placed in technology: better utilisation through controlled releases. In a concluding commentary by Aminu (1991, 1805), even environmentalism is again appropriated: "we will also ensure that the environment is fully protected, including the Ngwu [sic] Wetland which provides sanctuary to the migratory birds from Europe during the winter months." Aminu is deliberately mentioning Europe because the article he was referring to was written by a European.

\section{Opposition to the Kafin Zaki Dam}

Much of the prominent opposition to the project comes from the Nigerian Conservation Foundation (NCF), Borno and Yobe state governments, the North East Arid Zone Development Program (NEAZDP), the Hadejia-Nguru Wetland Conservation Project (HNWCP), and the Federal Environmental Protection Agency (FEPA). International agencies such as those of the European Union and the World Bank are also opposed to the project. The alliance does not involve grassroots organisations but works primarily through the structures of the state to influence policy makers. The NCF consists of some of the top elite of Nigerian society. For example, the former chair of the National Transitional Government, Ernest Shonekan (August-November 1993), was a former chair of the NCF.A.P. Leventis, of the Leventis conglomerate, is chair of the Scientific Committee of the NCF.

The NEAZDP is partially funded by the European Union and is implementing several other projects in the country. The HNWCP is a collaborative project of the Royal Society for the Pro- tection of Birds, the Nigerian Conservation Union, the Finnish Association for Nature Conservation and the World Conservation Union. The World Bank is also funding a small fadama (flood plain) irrigation project which covers some of the area in the Yobe Basin that could be negatively affected by the Kafin Zaki Dam. The Dam restricts the water that would have been used for small-scale irrigation projects. The FEPA is the environmental watchdog of the government. At the time of strong opposition to Kafin Zaki, the chairperson of the board of the FEPA was Bukar Shaib who is an indigene of the area most likely to be negatively affected by the dam construction.

Opposition to the project is based on technical, economic and environmental arguments. In a meeting initiated by the NCF with Ernest Shonekan, the NCF argued that, while controlled release could have a beneficial effect to downstream users, the technical efficiency and management of the Kafin Zaki Dam is suspect in light of previous experiences with similar projects. There is no guarantee that there is the technical and managerial capacity to release an adequate, timely water supply to downstream users. For example, when the Tiga Dam was completed, the Federal Government guaranteed 1,350 million cubic metres of water to pass through Gashua annually but this has not been implemented (HNWCP and NIPSS 1993, 3). In fact, even farmers in the upstream of the Kano River Project suffer great losses. Similarly, the Challawa Gorge Dam was closed in 1992 without any warning to the downstream users, leading to massive losses.

The economic problems relating to the dam have been identified as high capital cost, low yields, underestimation of the volume and values of existing production, high management costs, and especially poor returns for small irrigating farmers. The Kafin Zaki project is at best a "cathedral in the desert," just like its counterparts in many other parts of the country. The returns of the project promise to be 
minimal based on previous experiences. For instance, the three major irrigation schemes in northern Nigeria, Bakolori, Kano River Project and South Tchad, were expected to irrigate 320,000 hectares and 2 million hectares in 1982. But by 1982, the actual irrigated land was 30,706 hectares. By this same year, on the other hand, 800,000 hectares were irrigated by seasonal flooding. A study by Barbier (NEAZDP 1992,4) shows that net benefits in wetland small-scale irrigation are N239 per hectare compared to only N19 per hectare in the irrigated area of the Kano River Project. If the net benefits are assessed in terms of water productivity, then the net benefits per 1,000 cubic metre of water used in the wetland is N31.80 while in the Kano River Project it is N1.10. Indeed, studies by Kimmage and Adams (1992) have shown the superiority of indigenous use of wetlands in terms of not only the economics of production but ecological sustainability. (The comparison is made because of the negative impact Kafin Zaki would have had on small-scale irrigation in the wetlands).

NEAZDP, which more than any other organisation worked quietly to protect the Yobe Basin, estimates that current loss in production due to the dam from rice, small-scale irrigation, livestock production and fisheries at N730 million to N1.35 billion per year. The potential loss to production due to the dam from small-scale irrigation, livestock production, and fisheries is between N1.65 billion to 3 billion per year in 1990 in the Yobe state alone. Yobe and Borno States, two major states that provide livestock in the country, will be adversely affected. It is estimated that 1.5 million cattle and other livestock are in danger.

There are international dimensions of the economic losses as well. Hundreds of Niger Republic small-scaleirrigation cultivators and pastoralists depend on the flow of the river (NEAZDP 1992). Similarly, the implementation of the project would worsen the budgetary situation and damage the relationship between Nigeria and its creditors who would not see any basis for debt relief (Ogbonnaya 1993a, B1-2; Ogbonnaya 1993b, B4).

The ecological and human impact of the Kafin Zaki Dam project would have been very serious. In many cases, dams have resulted in extensive displacement, costly resettlement and discontent among those who are resettled. Other negative impacts include the collapse of traditional farming practices, its replacement by more vulnerable monocultural agriculture, threat to fishing, destruction of the wildlife sanctuaries in the wetlands and especially the Nguru and Dagona bird sanctuaries, and threats to transhumance (Synge 1991, 1536).

There are various experiences of water loss due to large dams in northern Nigeria. For example, when the Tiga Dam was completed in 1976, the river flow at Gashua was reduced by about 100 million cubic metres per year by irrigation and by more than 50 million cubic metres by evaporation. If the Kafin Zaki Dam is constructed it would result in the reduction in flow at Gashua by 1,275 million cubic metres per year. Moreover, Kafin Zaki would stretch 17 kilometres and create a reservoir of 235 square kilometres which would evaporate up to 450 million cubic metres of water per year. The losses due to evaporation to downstream users would be US $\$ 1$ million per annum (Martin 1993, 2; NEAZDP 1993, 2-3; Thompson 1993, 12). This is a major loss of water.

The construction of the Kafin Zaki Dam would have negatively affected ground water recharge in the basin. The recharging of the Tchad aquifer depends on the flood of the River Jama'are. The consequences of a disruption would be the shortage of water for human consumption, livestockand small-scale irrigation. The livelihood of about three million people would be jeopardised in Borno and Yobe states alone.

There are several other implications of the effects of the Kafin Zaki Dam. Identity conflicts would be intensified in the region, especially between pastoralists and small-scale-irrigation farmers. The pastoralists may be forced to migrate southward towards the Middle Belt which would only intensify the existing conflict in the region. Rural-urban migration would increase. This would only compound the current situation and probably lead to further social conflicts. On the other hand, pressure on tudu farming (upland), which is already overstretched, would increase. The lack of flow of the river system would only accelerate the process of sand dune formations and these would increase the process of desertification.

While the opposition to the project has a formidable argument, the alternative has not been clearly defined. There is, however, a wide feeling that there must be a mechanism to harness the water resources of the Yobe Basin by a single agency. At present the Yobe Basin is under the jurisdictions of the Chad Basin River Development Authority and the Hadejia-Jama'are River Basin Development Authority. This has led to several difficulties. For example, when the latter decided to close the Challawa Gorge Dam, this was not communicated to the former. Secondly, there is a need for a national policy on water resources. Thirdly, the opposition expects independent environmental reviews of projects (NEAZDP 1993).

\section{Conclusion}

This article shows that, while in many instances state and international agencies play a destructive role by funding mega-projects, this is not always the case. The politics of the Kafin Zaki Dam proposal shows that factions within these structures at times play a progressive oppositional role as the socially and environmentally disruptive effects become apparent.

\section{Notes}

1. The value of the Nara to US dollar was: N10 to US $\$ 1$ in 1990, N21 to US\$1 in 1992, and N85 to US\$1 in 1996.

\section{References}

Aminu, Abdul Ganiyu. 1991. “Livelihoods at Risk." West Africa (October 28-November 3): 1805. 
Gadzama, N. M. 1991. “Sustainable Development in Nigeria's Dry Belt." In Sustainable Development in Nigeria's Dry Belt, edited by K. O. Ologe, 5-18. Ibadan: NEST.

HNWCP (Hadejia-Nguru Wetlands Conservation Project), and NIPSS (National Institute for Policy and Strategic Studies). 1993. Workshop on the Management of the Water Resources of the Komadugu-Yobe Basin. Kuru: NIPSS.

Kimmage, Kevin, and W. M. Adams. 1992. "Wetland Agricultural Production and River Basin Development in the HadejiaJama'are Valley, Nigeria." Geographical Journal 158, no. 1, 1-12.

Martin, Alice. 1993. "Lake Chad in Danger of Disappearing." New Nigerian on Sunday (May 2): 7-8.

New Nigerian. 1993. (April 8): 16.

NEAZDP (North East Arid Zone Development Program). 1990. Water Resources Report. Damaturu: NEAZDP.

- 1992. Water Resources in the NEAZDP Area. Gashua: NEAZDP.

- 1993. "Report to the Committee on Water Management in the Komadugu Yobe Basin." Damaturu: NEAZDP.

Ogbonnaya, Obasi. 1993a. "Dams of Death." The Guardian on Sunday (August 1): B1B2.

- 1993b. "Those Dams Could be Damming." The Guardian on Sunday (April 18): B4.

Synge, Richard. 1991. "Livelihoods at Risk." West Africa (September 16-22): 1536.

Thompson, Henry. 1993. "Damming Nigeria's Wealth." World Rivers Review (Fourth Quarter): 12-3.

Watts, Michael, ed. 1987. State, Oil and Agriculture in Nigeria. Berkeley: University of California.

World Bank. 1990. Towards the Development of an Environmental Action Plan for Nigeria. Washington: The World Bank. $\square$

\section{Asylum: AMoral Dilemma By.W. Cunther Plnut

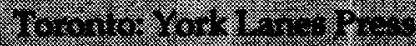

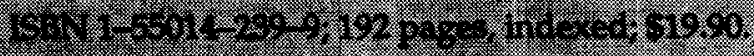

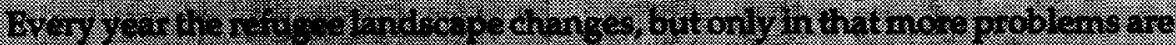

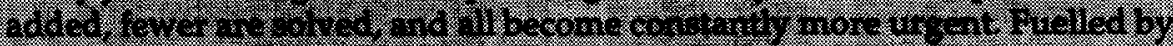
H. Pr

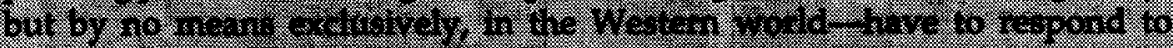

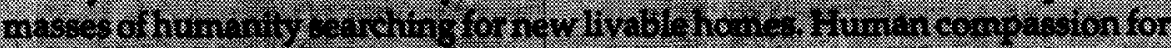

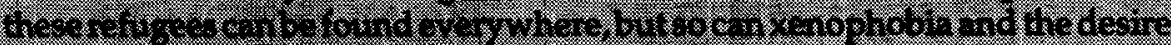

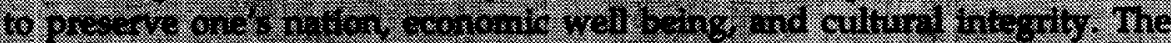

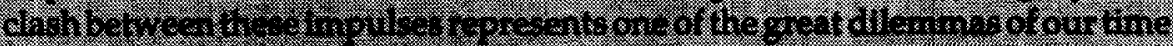

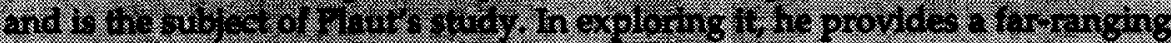

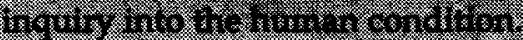

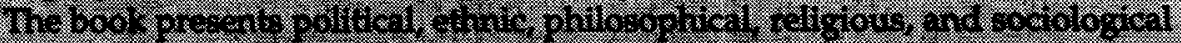

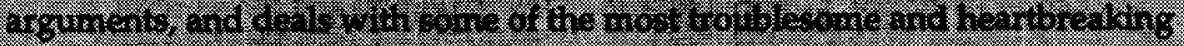

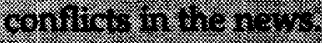

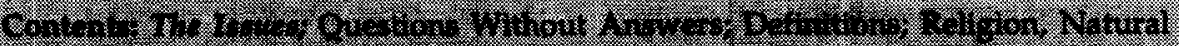

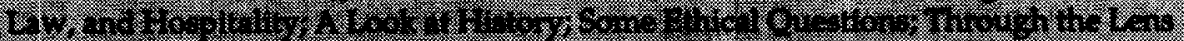

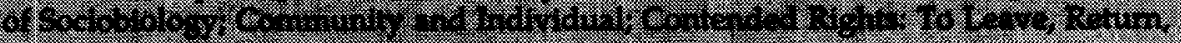

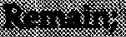

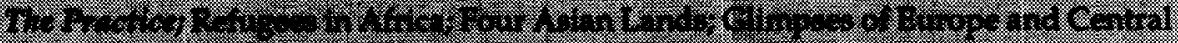

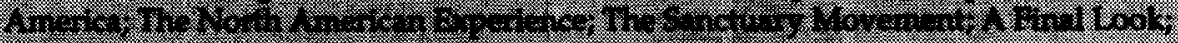

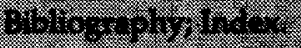

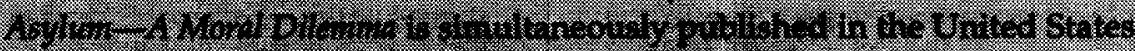

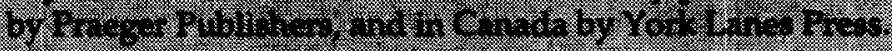

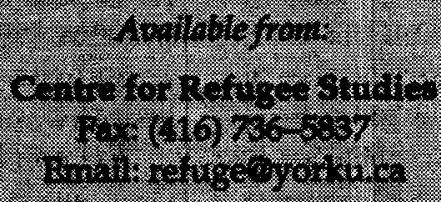

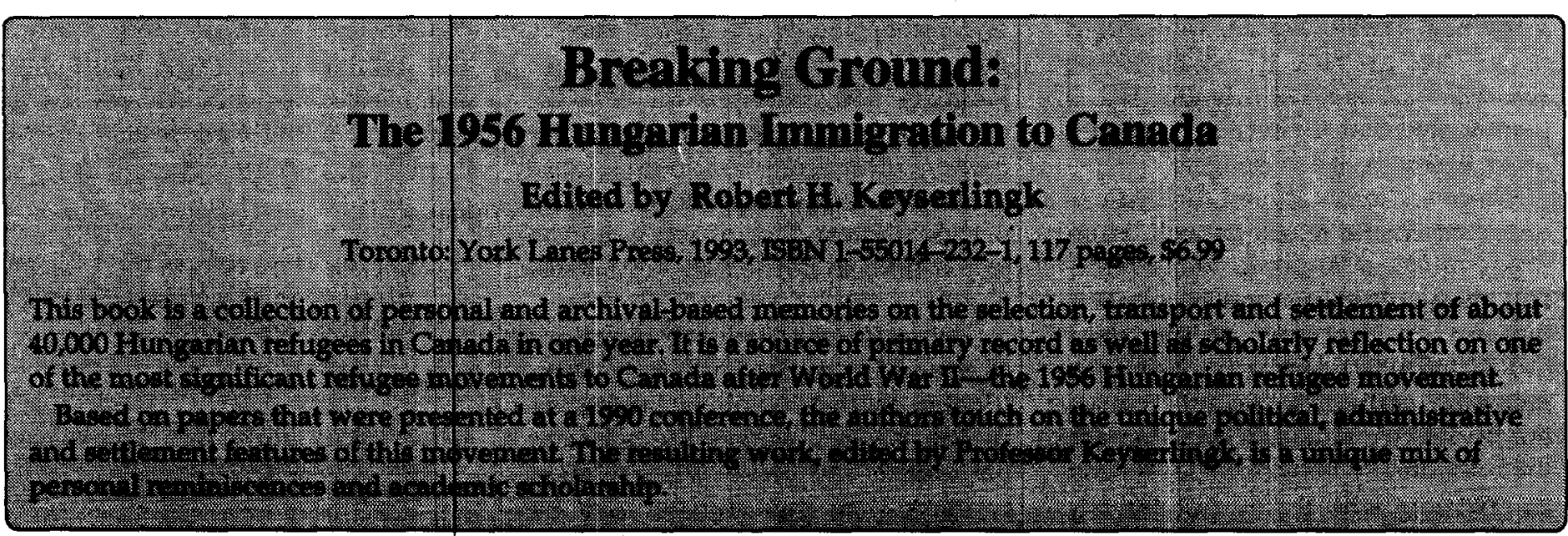

(C) Kole Ahmed Shettima, 1997. This open-access work is licensed under a Creative Commons Attribution-NonCommercial 4.0 International License, which permits use, reproduction and distribution in any medium for non-commercial purposes, provided the original author(s) are credited and the original publication in Refuge: Canada's Journal on Refugees is cited. 